\title{
Development of Learning Materials with Realistic Mathematics Education Approach to Improve Students' Mathematic Reasoning Ability and Self-Concept
}

\author{
Nenta Dumalia Siregar* Elmanani Simamora Izwita Dewi \\ Department of Mathematics, Science Faculty, State University of Medan, Jl. William Iskandar Ps.V, Kenangan \\ Baru, Sumatera Utara, Indonesia
}

\begin{abstract}
This study aimed to describe; 1) The validity, effectiveness, and practicality of learning materials with Realistic Mathematics Education; 2) Improvement of students' mathematics reasoning ability and student self-concept. This research is development research using the development model of Thiagarajan 4-D model. Learning materials that have met valid criteria according to experts, were tested in class VIII of SMP Muhammadiyah-22 Kisaran. From the results of trial I, trial II and disseminate stage were obtained : 1) the validity of learning materials that have met valid criteria according to experts; the effectiveness criteria are reviewed from: a) completeness of learning classical students; b) ideal time; c) positive responses of students to learning materials developed; and the practicality criteria based on the results of observations on the implementation of learning materials are included in the good category. 2) improvement of mathematical reasoning ability and self-concept of students using learning tools developed in terms of : a) The N-Gain score of the test of students' mathematical reasoning ability has increased, namely in the trial I was 75.78 increased to 86.91 in trial II and increased to 88.28 in the disseminate stage; b) Results of the average self-concept questionnaire in the trial I was 73.63 , increasing to 78.2 in the trial II and increased to 80.07 in the disseminate stage.
\end{abstract}

Keywords: RME, mathematic reasoning ability, self-concept

DOI: $10.7176 / \mathrm{JEP} / 10-23-10$

Publication date: August $31^{\text {st }} 2019$

\section{Introduction}

Education is one of the many pillars of a country's success. The role of education is important for the process of improving the ability and competitiveness of a nation in the world. To achieve the progress of a nation is largely determined by the quality of its education. Education has a very valuable and significant contribution to improving the quality of a nation (Muhardi, 2004).

In the world of education, mathematics is used as a compulsory lesson at every level in school. One of the basic competencies in mathematics is reasoning ability, that is important for students to have in learning mathematics. Reasoning skills are needed by students and all citizens when they study mathematics (Shadiq, 2004). This is in accordance with the statement that mathematical reasoning abilities are very important for successful mathematics learning, based on their ability to think logically (Nunes, 2010). Besides that, logical reasoning skills are important for mathematical learning that is successful and important for students' future careers (Marchis, 2016).

But in reality, many times students learn mathematical concepts without understanding them because some teachers teach them procedures without connections to their contextual experiences (Makonye, 2014). This was obtained when the researchers conducted preliminary observations in class VII-B SMP Muhammadiyah-22 Kisaran (7th-grade students) by giving a test question on mathematics reasoning abilities of students which were analyzed based on indicators of mathematic reasoning abilities. In this case, the researcher uses four aspects (four indicators modified based on the opinion of Maulana (2011) and Wardhani (2008)) to assess students' mathematical reasoning abilities, that is: (1) Proposing allegations; (2) Using patterns and relationships to analyze mathematical situations; (3) Compile and test the conjecture of the given contextual problems (4) Make conclusions, compile evidence, and provide reasons for the truth of the solution.

Based on the results of the analysis of the answers given by the students there are several indicators of mathematical reasoning abilities that students do not have, among others: students have not been able to put forward guesses in determining the right results to answer questions, use patterns and relationships to analyze mathematical situations. This makes students difficult in the problem-solving process so that the answers given by students are not as expected. Besides that, students also have not been able to compile and test the conjecture of the contextual problems given and estimate the answers and process of the solution. This makes students inaccurate in giving conclusions of answers and have not been able to provide explanations with their own words in the form of writing from the conclusions of the answers obtained. From the answer process, the students can show that students' mathematical reasoning abilities.

In addition to students' mathematical reasoning abilities, there are also aspects of psychology, that is self- 
concept which is also a factor that influences student success in solving mathematical problems. Self-Concept is the perception of someone who is physical, psychological, and social as a result of experience and interaction with others (Brooks, 1990). Mathematics self-concept is a person's assessment of his ability to learn mathematics (Douglas, 2000). A person's self-concept is strongly influenced by his social environment, the environment, experience, and parenting parents also have a significant influence on the formation of one's self-concept (Gecas, 1982). Children's self-concept consists of positive self-concepts and negative self-concepts (Calhoun \& Acoccella, 1990). Children who have higher positive self-concepts have more pleasant experiences than children with low self-concept (Andriasari, 2015).

But from the results of observations in the preliminary study conducted by the researcher, the learning atmosphere that occurred did not emphasize the activity of students, which students should be the center of learning. Students also feel reluctant to participate in answering questions given by the teacher. In addition, before trying to do exercises or questions, students often complain that the exercises or problems are difficult to solve. This indicates that self-concept students are still low, students do not have the confidence to express ideas and do not have confidence in the mathematical abilities they have to be able to complete the exercises given.

Another problem found is that the learning devices used by schools have not fully met the demands of the existing curriculum. Learning devices that are used less facilitate students to learn actively find their own concepts. Whereas, innovation in developing learning devices can lead students to discover mathematical concepts independently (Wijayanti \& Sungkono, 2017).

Based on the background description on section introduction, efforts need to be made to improve the implementation of learning, especially related to students' reasoning and self-concept abilities, namely by applying a particular approach. In this case, the researcher chooses to use the Realistic Mathematics Education (RME) approach. RME is a promising approach to mathematics learning (Hadi, 2017). The philosophy underlying realistic mathematics learning is that mathematics is seen as human activity (Freudenthal, 1991; Treffers \& Goffre, 1985; Gravemeijer, 1994; Moor, E. 1994; de Lange, 1996). So that mathematics must not be given to students in the form of 'results', but students must construct their own knowledge content through solving contextual problems interactively, both informally and formally. Hence, studies that focus on the effect of a learning approach on students' mathematical reasoning abilities which will ultimately improve mathematics learning outcomes and foster a positive self-concept in students, are important to do.

\section{Literature Review}

\subsection{Reasoning and Mathematical Reasoning Ability}

The reasoning is the thought adopted to produce statements and reach conclusions on problem-solving that is not always based on formal logic so that it is not limited to evidence (Lithner, 2008). Based on these opinions, it can be concluded that reasoning is an activity, a process, a thinking activity to draw conclusions or make a new statement that is correct and based on a statement whose truth has been proven or has been assumed previously. In line with Soekadijo (1997) who states that reasoning is the process of making conclusions from new proposals that were previously unknown, based on a number of propositions that are known or considered true. As one of the basic competencies of mathematics, the reasoning is also a mental process in developing the mind from several facts or principles.

Mathematical reasoning ability is one of the processes of thinking that is done by making a conclusion where the conclusion is a conclusion that has been valid or can be justified. There are two ways to draw conclusions that are inductive and deductive so that the term inductive reasoning and deductive reasoning are known (Wardani, 2008). The difference between deductive and inductive lies in the nature of the conclusions that are derived. Deductive is defined as the process of reasoning from general to special, while inductive is defined as the process of reasoning from special to general.

\subsection{Self-Concept}

Self-Concept is the views, judgments, and feelings of individuals about themselves that arise as a result of social interaction (Burns, 1993). The self-concept indicator used in this study are: (1) Dimensions of knowledge: relating to student participation in mathematics and students' views on the mathematical abilities they have; (2) Dimensions of expectation: relating to ideal mathematics learning about the benefits of mathematics and the active role of students in mathematics learning; (3) Dimension of assessment: which relates to how much students like mathematics, student interest in mathematics and math problems (Calhoun \& Acocella, 1995).

Hope about self determines how individuals will act in life. If an individual thinks that he can he tends to be successful. Conversely, if the individual thinks he or she cannot, it tends to fail. Self-Concept is also an assumption about the scheme of self, personal qualities which include physical appearance, psychological conditions, and sometimes also related to the main goals and motives (Baron \& Byrne, 1994). From some of the meanings from review of literature, it can be concluded that self-concept is an assessment, a person's view or belief about himself which is the result of interaction with the environment, which determines how someone will act in life. 


\subsection{Realistic Mathematics Education (RME)}

RME is a learning theory that starts from 'real' things for students, emphasizes the 'process of doing mathematics' skills, discussions and collaborations, argues with classmates so that they can find themselves ('student inventing' as opposed to 'teacher telling') ') and ultimately use mathematics to solve problems both individually and in groups (Zulkardi \& Ilma, 2010). There are five characteristics of the realistic mathematics education approach, namely: using context, using models for progressive mathematics, utilizing student construction results, interactivity and interrelationships (Treffers, 1987).

\subsection{Learning materials}

The materials are a number of devices, tools, media, instructions and guidelines that will be used in the process of achieving the desired activities. Learning is a learning process that is built by the teacher to develop creative thinking that can improve students' thinking skills, and can improve the ability to construct new knowledge as an effort to increase knowledge (Majid, 2011). Learning materials are tools or equipment to carry out a process that allows educators and students to carry out learning activities (Prasetyo, et. al, 2011).

To develop a set of learning materials fundamentally must be based on student characteristics (Uno, 2007). This is because the learning material that is developed in essence must help students to gain easiness in learning. In this case, the learning material that will be developed are: learning implementation plans, teacher book, student books, student worksheets, mathematical reasoning ability tests, and students' self-concept questionnaire.

\section{Research Methods}

This research was development research that used a model of development of Thiagarajan et al. (1974) which is also often referred to as 4-D, includes 4 stages namely define, design, develop and disseminate. The research focus was conducted at SMP Muhammadiyah-22 Kisaran, which is one of the junior high schools in Asahan, North Sumatera, Indonesia. Subjects in this study were students of class VIII of SMP Muhammadiyah-22 Kisaran. The object in this study is learning materials developed with Realistic Mathematic Education (RME) to improve students' mathematical reasoning ability and self-concept on pattern number topic, i.e. lesson plans, teacher book, student books, student worksheet, mathematic reasoning ability test, and student self-concept questionnaire.

The instruments used in this study were tests and questionnaires. Tests are used to measure mathematical reasoning abilities and questionnaires are used to see student responses. The Criteria for effectiveness of learning material seen from (1) Classical learning completeness of students at least $85 \%$ of students who get a test of mathematical reasoning ability have obtained a minimum score of 70; (2) At least 80\% of students respond positively to the components of the learning material developed; and (3) Learning time used does not exceed the usual learning time (Modified from Herman, 2012; Hasratuddin, 2018). Furthermore, the practicality criteria can be seen from the expert's assessment of the learning material developed which is stated to be able to be used with a slight revision or without revision, and from the observation of the implementation of learning material in the class of good or very good categories.

To analyze the improvement of students 'mathematical reasoning abilities, data were obtained from the results of students' pre-test and post-test. Improving students' mathematical reasoning abilities can be obtained from the gain index data normalized by Hake (1999), as follows:

$$
N-\text { gain }=\frac{\text { posttest } \text { value }- \text { pretest value }}{\text { ideal value }- \text { pretest value }}
$$

with the normalized gain index criteria $(\mathrm{g})$ shown in the following table:

Table 1. The Normalized Gain Score Criteria

\begin{tabular}{|c|c|}
\hline Gain score & Category \\
\hline $\mathrm{g}>0.7$ & High \\
\hline $0.3<\mathrm{g} \leq 0.7$ & Medium \\
\hline $\mathrm{g} \leq 0.3$ & Low \\
\hline
\end{tabular}

(Hake, 1999)

While the achievement measure used in the student's self-concept questionnaire was taken based on the Likert scale. To determine student answer scores, we applied scoring guidelines on the Likert scale for each statement, namely the score for each statement was 1 (strongly disagree), 2 (disagree), 3 (agree), and 4 (strongly agree).

\section{Result \& Discussion}

4.1 The Description of Learning Materials Development Stage

In this study, learning materials development with Realistic Mathematics Education (RME) have met the criteria of valid, effectiveness and practicality in trial II and the dissaminated stage. The results of the development learning materials using the Thiagarajan (1974) 4-D model are described as following.

4.1.1 Stage 1-Define

Based on observations in SMP Muhammadiyah-22 Kisaran found several weaknesses in the learning materials 
used by the teacher, because the teacher had not developed the lesson plan according to student characteristics, the subject matter in the book used by the teacher and students did not present non-routine problems such as contextual problem related to student environment, and the teacher does not use student worksheet as a support for learning activities. Furthermore, in the learning process, the teacher still uses a conventional approach, and the teacher is also not accustomed to giving confidence to students through motivational words so that students have a selfconcept in solving problems given.

4.1.2 Stage 2-Design

This stage produced an initial draft of the lesson plans for 5 meetings, student book, student worksheet, mathematics problem-solving ability test, and students' self-efficacy questionnaire. All result at this design stage is called draft I.

4.1.3 Stage 3-Develop

The revised draft I based on experts was then tested in this stage. The aim is to see weaknesses in the draft I so that it can be revised and refine the learning material developed. The results of expert validation in the form of content validity assessment indicate that all learning materials meet valid criteria, with a total average value of validation lesson plans is 4.38 , student worksheet is 4.47 , teacher book is 4.50 , and student book is 4.49 . All mathematics reasoning ability test items and questionnaires self-concept student meet valid and reliable criteria. Instrument reliability is used to determine test results. After calculation, the reliability of the mathematical reasoning ability test was 0.627 (high category) and the self-concept questionnaire was 0.891 (very high category).

After the learning materials developed have met the validity criteria, the learning materials in the form draft II were tested in the research subject and place, that is SMP Muhammadiyah-22 Kisaran, next after referred to as trial I. Based on the results of trial I data analysis, it was found that learning materials were developed did not meet all effectiveness criteria, so that improvements are made to produce learning materials that meet all the specified effectiveness criteria. Revisions were made based on findings from the weaknesses of the learning materials in the trial I, namely for lesson plans related to the allocation of learning time, as well as in student books and worksheets related to the material being taught. After the revision is complete, trial II is conducted to determine the effectiveness of the learning materials, as well as the improvement of mathematical reasoning ability and the attainment of students' self-concepts.

4.1.4 Stage 4-Disseminate

This stage is done by re-testing the learning materials in the research place, namely in class VIII-C with a total of 32 students. The test was conducted three times in accordance with the developed lesson plans with the aim of measuring the accuracy of the learning materials quality with a realistic mathematics education approach.

\subsection{Result of Trial I}

Based on the results of the trial I data analysis, it was found that the learning materials developed were not effective, because there were still some indicators of effectiveness that had not been achieved. The results of classical completeness in the mathematical reasoning ability of students in the trial I, namely in the pretest was $21.87 \%$ while the posttest was $71.87 \%$. This shows that students have not met the classical completeness criteria. The indicators of effectiveness that have been fulfilled in the trial I are the attainment of learning time, namely the learning time used is the same as ordinary learning time, besides that it is the response of students, namely students respond positively to learning material based on a realistic mathematics education approach with the average percentage of positive responses students in the trial I was $89.22 \%$.

Improvement of students' mathematics reasoning ability in the trial I was seen through N-gain from the results pretest and posttest of mathematic reasoning ability in the trial I. From the data obtained by students who received $\mathrm{N}$-gain score in the range of $\mathrm{g}>0.7$ or experienced an increase in mathematics reasoning ability with the "High" category as many as 2 students, students who experience an increase in mathematics reasoning ability with the "Medium" category or got $\mathrm{N}$-gain score of $0.3<\mathrm{g} \leq 0.7$ as many as 14 students and students who experience an increase in mathematics reasoning abilities with "Low" category or get $\mathrm{N}$-gain score of $\mathrm{g} \leq 0.3$ as many as 16 students. While the average N-gain in the trial I obtained 0.291 in the "low" category. Based on the data obtained on the attainment of the students' self-concept in the trial I most dominating is good category, which indicated that the students in the trial I has good self-concept.

\subsection{Result of Trial II}

Based on the results of the trial II data analysis, it was found that the learning materials developed have been effective based on indicators of the effectiveness of the learning materials that have been achieved. The results of classical completeness in mathematical reasoning ability of students in trial II, namely in the pretest was $31,25 \%$ while the posttest was $87,5 \%$. This states that students have met the value of classical completeness. Likewise, the learning time used is in accordance with the criteria for achieving learning time. Then the average percentage of the total positive responses of students in trial II was $92,03 \%$, so it can be concluded that students' responses to the components and learning activities were very positive. 
Improvement of students' mathematics reasoning ability from the data obtained in the trial II students who received $\mathrm{N}$-gain score in the range of $\mathrm{g}>0.7$ or experienced an increase in mathematics reasoning ability with the "High" category as many as 18 student, there were 7 students experienced an increase in mathematics reasoning ability with the "Medium" category or got $\mathrm{N}$-gain score in the range $0.3<\mathrm{g} \leq 0.7$ and 7 students experience an increase in mathematical reasoning ability in the "Low" category or got $\mathrm{N}$-gain score of $\mathrm{g} \leq 0.3$. The average gain in trial II obtained 0.604 in the medium category. Based on the data obtained on the achievement of self-concept students in the trial II most dominating is good and very good categories, which indicated that students in the trial II have a good self- concept.

\subsection{Result of Disseminate Stage}

Based on the results of the disseminate stage data analysis, it was found that the learning materials developed have met effectiveness criteria. The results of classical completeness in mathematical reasoning ability of students in this stage, namely in the pretest were $53,12 \%$ while the posttest was $90,63 \%$. This states that students have met the classical completeness criteria. The learning time used also matches the specified criteria. Furthermore, the average percentage of the total positive responses of students in the disseminate stage was $97.34 \%$, so it can be concluded that students' responses to the components and learning activities are very positive.

Improvement students' mathematics reasoning ability is also seen from the data obtained in this stage, as the N-gain criteria submitted by Hake (1999), students who received N-gain score in the range of $\mathrm{g}>0.7$ or experienced an increase in mathematics reasoning ability with the "High" category as many as 12 student, there were 17 students experienced an increase in mathematics reasoning ability with the "Medium" category or got $\mathrm{N}$ gain score in the range $0.3<\mathrm{g} \leq 0.7$ and 3 students experience an increase in mathematical reasoning ability in the "Low" category or got $\mathrm{N}$-gain score of $\mathrm{g} \leq 0.3$. The average gain in the disseminate stage obtained 0,627 in the medium category. Based on the data obtained on the achievement of self-concept students in the disseminate stage most dominating is good and very good categories, which indicated that students in this stage have a good selfconcept.

The description of the results of students' mathematic reasoning ability can be seen in the following table:

Table 2. Description of Mathematic Reasoning Ability Results

\begin{tabular}{|c|c|c|c|}
\hline Score & Trial I Posttest & Trial II Posttest & Disseminate Posttest \\
\hline \hline Highest Score & 93,75 & 93,75 & 93,75 \\
\hline Lowest Score & 43,75 & 62,5 & 62,5 \\
\hline Average & 75,78 & 86,91 & 88,28 \\
\hline
\end{tabular}

Based on Table 2 shows that results of posttest students' mathematics reasoning ability analysis of trial II and disseminate stage have met classical completeness criteria. This because the material and problems in the student book and worksheet were developed according to the characteristics and environment of students, so students could use their previous experiences and utilizing knowledge from their daily environment to solve a mathematics problem that makes the learning process more meaningful. This is in accordance with Ausubel's learning theory which states that meaningful learning is a process of linking new information or material with concepts that already exist in one's cognitive structure (Trianto, 2011). Cognitive structures are facts, concepts, and generalizations that students have learned and remembered. This means that meaningful learning occurs when students try to connect information or new material in the structure of knowledge to solve the problems they face.

In addition, student learning completeness is also influenced by the learning approach used in the learning process, which is a realistic mathematical approach that makes students interested in learning and actively involved in the learning process. This is in line with what was stated by Veloo et al. (2015) in their study that most students taught with a realistic mathematics education approach have achieved better results in mathematical analog reasoning and generalization than students taught by conventional approaches. Another study by Kusumaningrum (2016) states that the achievement of mathematical reasoning abilities and learning independence of students who get learning with a realistic mathematics education approach is better and relatively high than students who get conventional learning. Supported by the results of the research by Fuadiah et al. (2009) which concluded that there was an increase in the completeness of student learning outcomes from the trial I to trial II which gained realistic learning for students' mathematical abilities. Furthermore, the results of research conducted by Wulandari et al. (2014) show that RME-based learning material developed is included in effective categories in terms of students' classical learning completeness.

The achievement of learning time with the RME approach meets the effectiveness criteria. This is because learning takes place by linking material and contextual problems that match the characteristics of students so that students are active in the learning process and the teacher can use the time as effectively as possible for the success of the learning process. As stated by Slavin (2006) that the length of time given to students to study the material presented is something that must be considered by the teacher because learning will take a lot of time. The same thing was also stated by Yuliani \& Saragih (2015) that the research learning time used must refer to the usual 
learning time criteria so that the learning time must be planned by the teacher in order to create effective and efficient learning. Thus it can be concluded that the achievement of learning time shows that the use of learning tools developed meets the criteria of effectiveness.

Based on the results of the analysis of the results of trial I, trial II and the disseminate stage, it was found that the average percentage of student responses in each trial was positive, meaning that overall students felt helped and happy with the learning tools developed with RME approach. Student responses given at each trial have reached the predetermined criteria, namely $\geq 80 \%$. This shows that learning material developed with RME approaches have met effective criteria. In line with that, the results of the study by Daryanto (2007) state that the actions or students responses are the results of interaction with the environment. This is because the learning process is complex, where students determine whether they will learn or not. In addition, the positive response given by students is inseparable from several factors, one of which is the application of learning material with RME approaches in the learning process. This is also supported by the results of research by Maulydia, et al (2017) which states that students' responses to learning material that has been developed through RME are positive because more than $80 \%$ of students are interested in participating in teaching and learning activities with developed learning tools. From the description of this section, it can be concluded that learning material developed with the RME approach contribute positively to students' responses to learning.

The practicality of learning material can be seen based on the results of data analysis from the results of trial I, trial II and the disseminate stage. The summary of observations on the implementation of mathematics learning with the RME approach in each stage can be seen in the following table :

Table 3. The Summary of Observations on the Implementation of Mathematics Learning

\begin{tabular}{|c|c|}
\hline Stage & $\begin{array}{c}\text { Percentage Average } \\
\text { Implementation of Learning }\end{array}$ \\
\hline \hline Trial I & $82,3 \%$ \\
\hline Trial II & $88,7 \%$ \\
\hline Disseminate & $89,7 \%$ \\
\hline
\end{tabular}

Table 3 shows that the average percentage of learning implementation in the trial I was $82.3 \%$, in the trial II was $88.7 \%$ and in the disseminate stage was $89.7 \%$. Thus it can be concluded that the implementation of learning at each stage has met the practicality criteria and is in a good category $(80 \leq \mathrm{k}<90)$. Improvement of students 'mathematical reasoning ability can be seen based on the calculation of N-Gain results of tests of students' mathematical reasoning abilities in the first trial, trial II and the deployment stage shown in the following graph.

Graph 1. Improvement of students 'mathematical reasoning ability from the N-gain scores

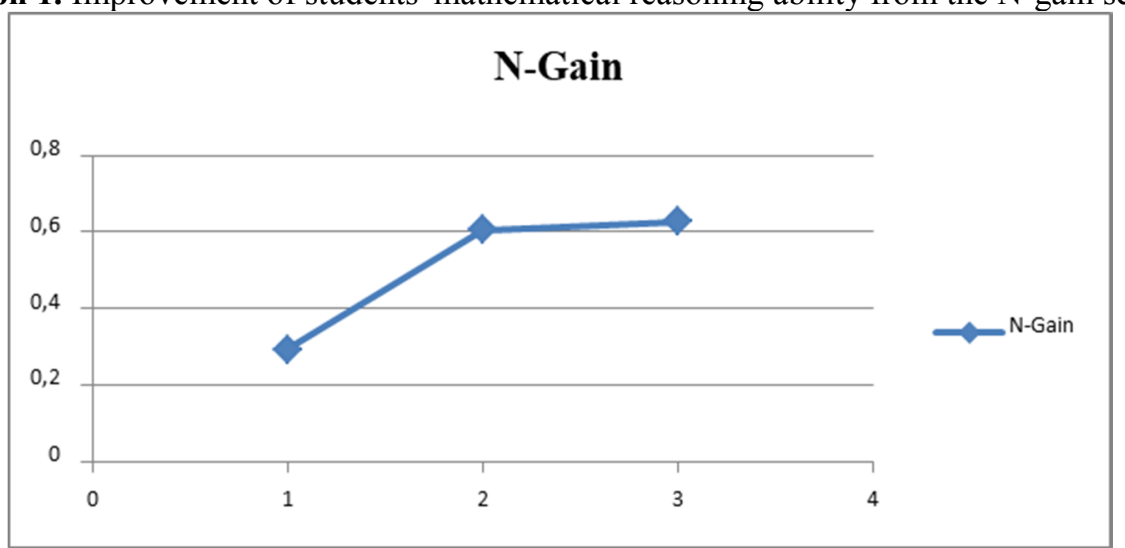

Based on grah 1 it can be seen that results of the test of students 'mathematics reasoning ability in the trial I, trial II and disseminate stage showed that there was an improvement in students' mathematics reasoning ability from the $\mathrm{N}$-gain scores obtained. In the trial I, the $\mathrm{N}$-gain score obtained was 0.291 , in the trial II it increased to 0.604 and in the disseminate stage it increased to 0.627 . Improvement of students' mathematics reasoning ability due to the learning process using learning material with the RME approach beginning with contextual problems, so that students can use their previous experience in understanding and solving mathematical problems given. As Lestari \& Wijayanti (2016) said in their study which showed that there were significant differences in the average $\mathrm{N}$-gain mathematic reasoning ability between students who obtained mathematics learning with realistic mathematics education approach and classes that obtained mathematics learning with the conventional approach. This is also supported by the results of research by Kusumaningrum (2016) state that the achievement of mathematical reasoning ability and learning independence of students who get learning with a realistic mathematics education approach is better and relatively high than students who get conventional learning.

Based on the results of the questionnaire self-concept data analysis of students in the trial I, trial II and the disseminate stage showed that there was an increase in student self-concept. It can be seen from the average results 
of self-concept questionnaires filled by students. The total score of the average score of the questionnaire selfconcept students in the trial I was 73.63 , increasing to 78.2 in the trial II and the disseminate stage increased to 80.07. This shows that the use of learning material developed with RME approaches has an impact on improving student self-concept.

\section{Conclusion}

Based on the results of the analysis and discussion in this study, it can be concluded that learning materials with the approach of Realistic Mathematics Education (PMR) has met the criteria of validity, effectiveness, and practicality, and mathematic reasoning ability and students self-concept have increased. This study shows that learning materials with the RME approach are important things to consider in an effort to maximize students' mathematics learning achievements. It is recomended for other researchers who will conduct research to measure students' mathematical reasoning ability so that they pay more attention to indicators make conclusions, compile evidence for the truth of the solution in making proofs of solving contextual problems given into the form of mathematical models in the form of symbols or equations and solving them, as well as pay more attention to the self-concept indicators especially the knowledge dimension that is related to participation and views of students on the mathematical ability they have.

\section{References}

Andriasari, F. (2015). Konsep Diri Pada Anak Sekolah Dasar dan Menengah Pertama. Psychology Forum UMM, ISBN: 978-979-796-324-8.

Baron, R.A \& Byrne, D. (1994). Social Psychology: Understanding Human Interaction. Boston: Allyn \& Bacon. Brook E. (1990). The Psychology of Adolescence. Third Edition. New Jersey : MacMilland Publishing. Co. Inc.

Burns, R. B. (1993). Konsep Diri: Teori, Pengukuran, Perkembangan, dan Perilaku. (Translator: Eddy). Jakarta: Arcan.

Calhoun, James F. and Acocella, Joan R. (1990). Psychology of adjustment human relationtship(3th ed). New York : McGaw-Hill.

Calhoun, James F. and Acocella, Joan R. (1995). Psikologi Tentang Penyesuaian dan Hubungan Kemanusiaan (Translated by Satmoko), R.S. Semarang: IKIP Press.

Daryanto. (2010). Belajar dan Mengajar. Bandung: YramaWidya.

Douglas, A. (2000). Math Anxiety, Math Self Concept, and Performance in Math. Canada : Faculty of Education Lakehead University.

Fauzi, KMS. M. A. (2002). Pembelajaran Matematika Realistik pada Pokok Pembahasan Pembagian di SD. Tesis pada PPs UNESA: Tidak diterbitkan.

Fuadiah, N. F, Zulkardi, dan Hiltrimartin, C. (2009). Pengembangan Perangkat Pembelajaran pada Materi Geometri dan Pengukuran dengan Pendekatan Pendidikan Matematika Realistik Indonesia di SD Negeri 179 Palembang. Jurnal Pendidikan Matematika, Vol.3 No.2, Desember 2009 Hlm. 73-84.

Gecas, V. (1982). The Self-Concept. Annual Review of Sociology, Vol. 8 (1982), pp. 1-33. http://www.jstor.org/stable/2945986 .

Hadi, S. (2017). Pendidikan Matematika Realistik. Jakarta: PT. Raja Grafindo Persada.

Hake, R. R. (1999). Analizing Change/Gain Scores. Woodland Hills: Dept. Of Physics, Indiana University.

Hasratuddin. (2018). Mengapa Harus Belajar Matematika?. Medan: Penerbit Perdana Publishing.

Herman. (2012). Pengembangan Perangkat Pembelajaran Model Pengajaran Langsung untuk Mengajarkan Materi Kesetimbangan Benda Tegar. Jurnal Sains dan Pendidikan Fisika, (Online), Jilid 8 Nomor 1, April 2012 hlm 1-11, (http://digilib.unm.ac.id/download.php?id=236).

Kusumaningrum, D.S. (2016). Peningkatan Kemampuan Penalaran dan Kemandirian Belajar Matematik Melalui Pendidikan Matematika Realistik Indonesia (PMRI)Untuk Siswa SMP. Jurnal Buana Ilmu. ISSN :2451-6995, Vol.1, No.1, November 2016.

Lestari, I. Prahmana, R.C.I. dan Wiyanti, W. (2016). Peningkatan Kemampuan Penalaran Matematis Siswa Menggunakan Pendekatan Pendidikan Matematika Realistik. Jurnal Inbovasi Pendidikan Dasar, Vol.1 No.2, 1-8, 2016. ISSN Cetak:2477-3859. ISSN Online :2477-3581.

Lithner, J. (2008). A Research Framework for Creative and Imitative Reasoning. Education Study Mathematic, Vol.67 No.3 (Mar.2008), 255- 276.

Majid, A. (2011). Perencanaan Pembelajaran Mengembangkan Standar Kompetensi Guru. Bandung : PT. Remaja Rosdakarya Cetakan VII.

Makonye, J.P. (2014). Teaching Function Using a Realistic Mathematics Education Approach : A Theoretical Perspective. International Journal Education Science 7(3): 653-662.

Marchis, I. (2013). Pre-Service Primary School Teacher's Logical Reasoning Skills. Acta Didactica Napocensia. Volume 6, Number 4,2013.ISSN 2065-1430.

Maulana. (2011). Dasar-dasar Keilmuan dan Pembelajaran Matematika Sequel 1. Subang: Royyan Press. 
Maulydia, S. S.; Surya, E. \& Syahputra, E. (2017). The Development Of Mathematic Teaching Material Through Realistic Mathematics Education To Increase Mathematical Problem Solving Of Junior High School Students. IJARIIE. Vol. 3, No. 2

Muhardi. (2004). Kontribusi Pendidikan Dalam Meningkatkan Kualitas Bangsa Indonesia. Jurnal Manajemen. FE. Universitas Islam Bandung. Volume XX No. 4 Oktober - Desember 2004 : 478 - 492

Nunes, T. et al. (2010). The Contribution of Logical Reasoning to the Learning of Mathematics in Primary School. British Journal of Developmental Psychology, 25,147-166. DOI: 10.1348/026151006X153127

Prasetyo, Zuhdan Kun, dkk. (2011). Pengembangan Perangkat Pebelajaran Sains Terpadu untuk Meningkatkan Kognitif, Keterampilan Proses, Kreativitas serta Menerapkan Konsep Ilmiah Peserta Didik SMP. Yogyakarta: Program Pascasarjana UNY.

Shadiq, F. (2004). Pemecahan Masalah Penalaran Dan Komunikasi. Yogyakarta : PPPG Matematika.

Slavin, R. E. (2006). Educational Psychology, Theories and Practice. Eighth Edition. Masschusetts: Allyn and Bacon Publishers.

Soekadijo. (1997). Logika Dasar Tradisional, Simbolik, dan Induktif. Jakarta: Gramedia. (Online). Jurnal Uny. Tersedia pada : http//prints.uny.ac.id/181e2/1.pdf.

Thiagarajan, S.; Semmel, D. S. \& Semmel, M. I. (1974). Instructional Development for Training Teachers of Exceptional Children. A Sourcebook Indiana: Indiana University.

Treffers, A. (1987). Three Dimensions a Model of Goal and Theory Description in Mathematics Education. Dordrecht : Reidel, The Wiscobas Project.

Trianto. (2011). Mendesain model pembelajaran Inovatif-Progresif, Konsep, Landasan, dan Implementasinya pada KTSP. Jakarta: Kencana Prenada Media Group.

Uno, Hamzah B. (2007). Model Pembelajaran Menciptakan Proses Belajar Mengajar yang Kreatif dan Efektif. Jakarta: Bumi Aksara.

Veloo, A. Ali, R. M and Ahmad, H. (2015). Effect of Realistic Mathematics Education Approach Among Pubic Secondary School Students In Riau, Indonesia. Australian Journal of Basic and Applied Sciences. 9(28) Special 2015, Pages: 131-135 ISSN:1991-8178.

Wardhani, Sri. (2008). Analisis SI dan SKL Mata Pelajaran Matematika SMP/MTs untuk Optimalisasi Tujuan Mata Pelajaran Matematika. Yogyakarta: Departemen Pendidikan Nasional.

Wijayanti, S. \& Sungkono, J. (2017). Pengembangan Perangkat Pembelajaran mengacu Model Creative Problem Solving berbasis Somatic, Auditory, Visualization, Intellectually. Al-Jabar: Jurnal Pendidikan Matematika. Vol. 8, No. 2, 2017, Hal 101 - 110. p-ISSN: 2086-5872. e-ISSN: 2540-7562.

Wulandari, R.; Sunardi; \& Indah, A. (2014). Pengembangan Perangkat Pembelajaran Berbasis Pembelajaran Matematika Realistik Pokok Bahasan Kubus Dan Balok. Pancaran, Vol. 3, No. 1, hal 131-140, Februari 2014

Yuliani, K dan Saragih, S. (2015). The Development of Learning Devices Based Guided Discovery Model to Improve Understanding Concept and Critical Thinking Mathematically Ability of Student at Islamic Junior High School of Medan. Journal of Education and Practice IIST. Vol. 6, No.24:116-128.

Zulkardi \& Ilma. (2010). Pengembangan Blog Support Untuk Membantu Siswa dan Guru Matematika Indonesia Belajar Pendidikan Matematika Realistik Indonesia (PMRI). Jurnal Inovasi Perekayasa pendidikan (JIPP). Vol.2, Issue 1, 1-24. 